\title{
Study on Pottery-art Course Teaching in Colleges and Universities Based on Regional Resource Advantage
}

\author{
Wenjuan Zhang \\ School of Arts \\ Handan College \\ Handan, Hebei, China 056005
}

\begin{abstract}
With arising of modern pottery-art, people gradually understand aesthetic education effect of pottery-art. Many comprehensive academies and local colleges and universities successively set up pottery-art course. As one of local colleges, our school also set up pottery-art course according to its own features. The author constantly tries and explores with combination of teaching reality, analyzes our school's regional resource advantage for setting up pottery-art course and discusses course content setting, teaching mode, teaching method and other aspects. The author thinks that in order to make pottery-art course teaching impressive, development of potteryart course in college should combine with its own regional features, school running level and major direction, and fully use existed art resource to adopt its good points and avoid its shortcomings.
\end{abstract}

Keywords-cultural resource; pottery-art course; practice; teaching

\section{INTRODUCTION}

Pottery-art education in domestic institutions of higher learning derives from professional ceramic in Jingdezhen Porcelain and Ceramics College and Central Academy of Fine Arts in 1950s and 1960s at the earliest. Since reform and opening-up in 1990s, with emergence of modern pottery-art in China, China's fine art colleges successively set up department or studio of pottery-art major and form pottery-art teaching systems with distinctive features. After the 20th century, pottery-art becomes a subject with rapid development in various fine art colleges and it begins to appear in teaching of Arts Department in various colleges and local colleges. In this kind of colleges, pottery-art does not appear as a systematic and professional direction. Instead, it appears as a optional course or a compulsory course of art theory, aiming to popularize ceramic culture, cultivate people's taste and cultivate students' comprehensive practical ability.

As a local comprehensive university, our school also sets up pottery-art course aiming at students of art major. However, establishment of pottery-art course can not go with the stream. Since pottery-art has a very wide range, class hour of potteryart course in regular institutions of higher education is relatively short, it is impossible to follow professional potteryart teaching's teaching content and teaching method. Instead, they should keep a foothold in local regional cultural

Fund project: Humanistic and social science research project of institutions of higher learning in Hebei province in 2016 - "Research on Injection of Regional Cultural Resource into Art Course Teaching in Colleges — Taking Cizhou Kiln Culture as An Example” Project No.: 【SZ16205】 . advantages, and explore pottery-art teaching mode suitable for their training objectives and with their own features. This paper takes pottery-art course teaching of Handan College as an example and analyzes course setting and teaching mode of pottery-art course teaching to provide reference for and communication with relevant colleges' similar course teaching.

\section{Profound Regional Resource Culture Provides THE BASIS FOR POTTERY-ART TEACHING}

Regional cultural resource is not only cohesion of local culture, but also a kind of resource of art and design education course. In pottery-art teaching, we should take local culture and traditional resource as the subject of teaching content and forge characteristic practical teaching to serve local economic and cultural construction fundamentally.

Our school is a local college in Handan, Hebei, which belongs to northern porcelain area and is also the location of Cizhou kiln culture. Cizhou kiln is the largest folk kiln in northern China with extremely distinct folk kiln features. From creation of firing in the Northern Qi dynasty until now, it still conducts firing without intermission. It is an extremely important kiln eye in ceramic history. Cizhou kiln products have various varieties and their basic feature is applying engobe. They combine with Chinese traditional painting and calligraphy skills and ceramics to create new art and to expand new view of ancient ceramic aesthetics. Even to this day, Cizhou kiln ceramic art still enjoys great popularity in the world's culture field and applied art circle. In recent years, although the ceramic producing area of Handan develops not as rapidly as Tangshan in Hebei, Jingdezhen in Jiangxi, Zibo in Shandong, Foshan in Guangdong and so on, Handan ceramic with Cizhou kiln culture as representative continuously innovates in inheriting all the time and it is still a powerful support of local cultural industry. Based on cultural resource advantage of this area, in 2008, Academy of Arts of Handan College sets up pottery-art course, which has important significance on our school's building a famous local college and cultivating applied talents. On the one hand, pottery-art course takes ceramic clay as basic material. Ceramic clay has flexible plasticity and can produce abundant artistic effects through application of techniques and it is a rather good carrier to cultivate students' operational ability and innovative ability. On the other hand, establishment of this course is also adaptation to local educational reform and the 
need to cultivate applied and practical talents. Rich Cizhou kiln cultural deposit provides profound artistic resources for pottery-art teaching. As producing area of ceramic, it provides great convenience for purchase of local blue soil, large cylinder mud and mineral as teaching material and it is solid material resource of pottery-art teaching. Many ceramic manufacturers and employees also provide practice field and technical support for pottery-art teaching. Many regional cultural advantages make our school's pottery-art course emphasizing on digging local material resource, giving play to local material advantage and saving teaching cost in teaching. Thus our school forms its own local features.

\section{PotTery-ARt Course CONTENT SETTING}

As a kind of special art form, pottery-art combines with multiple kinds of aesthetic languages of modeling, decoration, material, technology and so on. Pottery-art also has rich expressive force and it can bear various forms of sculpture, painting, environment, device and so on. Pottery-art course set up in professional academies has detailed classifications. In local colleges, pottery-art course is limited by class hour, thus course teaching can only be carried out according to cultivation objectives purposefully.

Selection of course content and teaching method is the important basis for realization of objectives of course setting. They should pay attention to the status of pottery-art course in the entire course setting, implementation of teachers, position of this course in the major, difference in students' background, which kind to take to show principle of justice and professional features of the course. Our school's pottery-art course setting mainly faces sophomores of bachelor degree of art theory and art and design major. They have certain artistic foundation. However, their modeling ability is weak and their knowledge of pottery-art is not adequate. Therefore, there is certain difficulty in making students know about this course and give play to their innovation ability in a short period of time. We should gradually guide students in getting familiar with basic properties of ceramic material, make students master basic molding techniques of ceramic and so on, advocate teaching students in accordance of their aptitude, find out personal features of students in time, train students to use their own advantage and train their creation capability.

Pottery-art course content is mainly divided into the following several aspects: Firstly, it is storage of theoretical knowledge. Learning content should be basic knowledge of pottery-art. The teacher should introduce artistic features and material features of pottery-art, make students know about development and current status of China's traditional ceramic and modern pottery-art and make students learn to appreciate works' sense of beauty and know about form of works to deepen their understanding of the artistic form of pottery-art; Secondly, learn basic molding techniques of pottery-art, such as hand pinching molding, mud slice molding, mud strip molding and so on to make students familiar with language features of ceramic material and make them able to complete simple pottery-art production individually; Thirdly, learn and innovate traditional craft. Make students learn decoration methods of pottery-art, mainly emphasizing on learning of Cizhou kiln decoration technique; fourthly, comprehensively apply learned molding methods and decoration and combine with their own professional advantages to complete creation of works. In teaching process, particular emphasis should be put on students' major. Students of art theory major should aim at features of demonstration specialty and emphasize on training of pottery-art knowledge and pottery-art molding skills to adapt to employment's need of pottery-art course teaching in middle school and primary school in future. However, art and design major and plane or space direction emphasize on using features of ceramic to give play to innovativeness and encourage diversity of creation form.

\section{CONSTANT EXPLORATION ON TEACHING MODEL AND TEACHING METHOD}

With pushing forward of educational reform, our school constantly adjust pottery-art course teaching to adapt to new educational concept. In recent several years' teaching, potteryart course constantly summarizes experience, adopts the form of combination of studio on campus and practice base outside the school to conduct practice teaching, invites ceramists to get into the school to give lectures as useful supplement of teaching through organizing pottery-art club and holding pottery-art works communication exhibition, creates cultural atmosphere of pottery-art and combines with local culture to promote conversion of teaching results into market.

\section{A. Give Play to Efficacy of Studio on Campus}

Pottery-art creation has strong usability and procedural character. From selection of mud material, molding and glazing to the final firing, each step has certain rules. Establishment of pottery-art practical training studio satisfies requirements of basic pottery-art teaching and makes students fully experience the whole process of pottery-art creation. Studio on campus bears main tasks of classroom teaching. Teachers use various teaching methods of guiding, demonstration, interaction and so on to guide students in active exploration. Namely, teachers use multiple methods to guide students in active exploration and using correct methods to learn pottery-art and arouse students' interest in pottery-art creation; Teachers' demonstration makes students familiar with essential points of operation and master basic skills; Group cooperation and interaction between teacher and student are adopted to cultivate students' operational ability and communicative ability and demonstrate students' individual value and subject creation sense; In addition, teach development history, school of art, molding, decorative methods and other knowledge of ceramic in details in the form of character, picture, video and so on. Make students do practice exercises in studio to get familiar with features of ceramic material, master basic molding and decoration method of pottery-art, realize limited factors of craft condition faced by pottery-art creation and lay a solid foundation for subsequent modeling creation. Of course, teaching and practice along can not achieve teaching purpose. Studio on campus fully opens up and students can fully use their spare time to learn independently and give play to their personality.

The studio also shoulders activities of pottery-art mass organization. Pottery-art organization is formed as a pottery-art communication and learning platform for students loving 
pottery-art. When the course is over, students can still use equipment and conditions in studio to do pottery-art creation. Usually, under the guidance of teacher, a topic is formulated in each phase, such as zodiac porcelain gift, cup, flower receptacle and so on. Thick atmosphere will promote students' passion to learn. Students use green color decoration method to make zodiac porcelain gift in class and in their spare time "Fig. $1 "$.

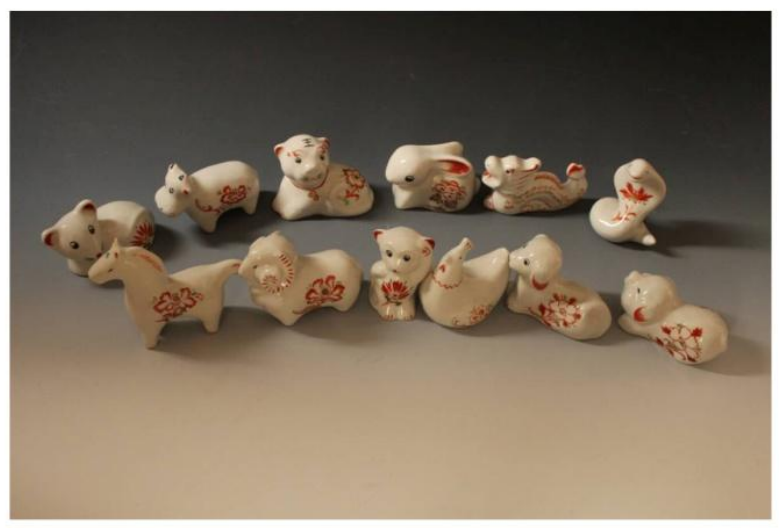

Fig. 1. Zodiac Porcelain Gifts by Han Caihong and Li Leilei

\section{B. Establish Cooperation with Off-Campus Practice Base}

It is an effective means of practice teaching to cooperate with local enterprises and construct off-campus internship base. By doing this, students can not only apply their knowledge learned in class flexible in pottery-art practice, but also feel enterprise's requirement of ability. Practice base has the responsibility to cultivate students for the academy. Our school and Great Master Pottery-Art Limited Company producing Cizhou kiln ceramic sign a internship base agreement, making up for limitations of classroom teaching and providing an excellent practice site for students to learn traditional Cizhou kiln craft. Here, students can directly learn about a stack of soil which seems ordinary, how to make unfired brick and final production of fine ceramic ware in exhibition room after firing. An eyeful of goodies of ceramic products in workshop, largescale production equipment, master workers' skillful throwing technique, mass slip casting, roller forming, immersed glazing, glazing by pouring, encastage firing and other working procedures widen students' horizon. Cizhou kiln culture and art gallery's artwork of different eras and modern and contemporary artists' works in factory area provide rich creation resource for students. Students experience production process of products on their own and learn traditional techniques of Cizhou kiln here, such as scraping and carving on white ground and black decoration on white ground. Students create pottery-art works with local features according their interests and features. A short period of practice is not adequate to make students have good creative ability and skillful craft. But it creates good conditions to cultivate students' interest and passion in Cizhou kiln art, makes students know about profound and broad Cizhou kiln culture and realizes combination of design concept and practical production initially at the same time.

\section{Combine with Local Culture to Promote Marketization of Teaching Achievements}

Chinese culture is long-standing and well-established and has its own cultural features in different regions. Handan in Hebei is a famous city of historical culture. Thousands of years of civilization forms Zhao culture, dream culture, Yedu culture, grotto culture, Cishan culture, Cizhou kiln culture, auxiliary capital culture, Tai Ji culture, proverbs and allusions culture, modern revolution culture and so on, 10 large cultural vein systems in total. This culture not only provides many new spaces and chances for development of art education of local colleges, but also is inexhaustible and endless resource of pottery-art course. Pottery-art course teaching also emphasizes on combination with local culture and carries out multipletopic practice teaching, like making students create works around the topic of Tai Ji culture in creation phase; Students design and create several ceramic works around the activity of "design of Jize". Among them, ceramic cups showing Mao Sui culture in Jize is outstanding from the crowd "Fig. 2"; Besides, make students actively participate in topic of developing ceramic tourist souvenir based on pottery-art studio and lead students in surveying ceramic storefront in Handan city, tourism market of Handan, Handan Museum, production craft of Guantao and black pottery, Pengcheng, $\mathrm{Ci}$ county and some other places, aiming to learn about current sales of Handan tourist souvenir and important categories and popularity of ceramic products, find out market vacancy, make plans and design a series of ceramic products. Students design and create goat zodiac porcelain and create small-scale cinnabar -Buddha incense insert and some other products for Xiangtangshan grotto scenic spot. Many good designs are directly adopted by schools or enterprises, promoting marketization of teaching achievements. Colleges should put up a communication bridge for students' pottery-art course and market and feedback of various information in the market should be made to teaching in order to make students know about market need. Our school also establishes market for students' works through launching "flea market" on weekends, thus students' passion for learning increases a lot and students' subjective initiative of study and confidence are improved.

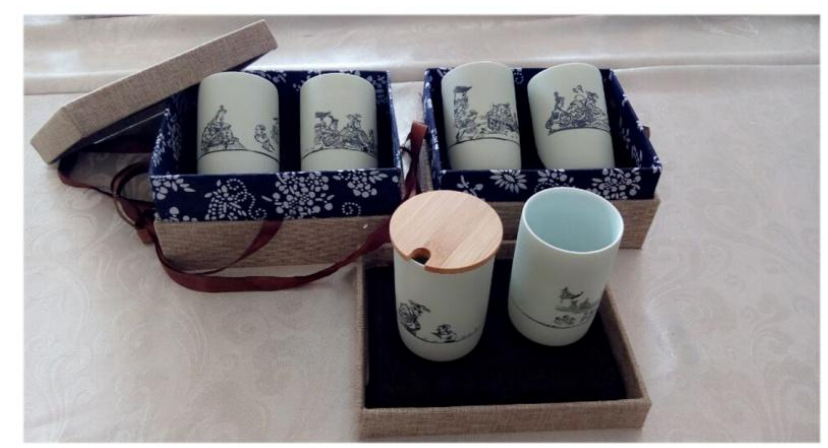

Fig. 2. Recommending Ceramic Cups by Chen Linlin

\section{CONCLUSION}

In recent several years, our school's pottery-art course teaching makes meager contributions to heritage of Cizhou kiln culture and innovative development of pottery-art and it 
combines with local cultural industry, indirectly pushing forward development of local economy and conforming to local college's objective of cultivating applied talents adapting to economic and cultural construction development requirement. Of course, there are many problems to solve in teaching, such as weak basic ability of students due to their enrollment level, limited course time and difficulty in creating highly innovative works of high level. Pottery-art course teaching needs improvement in practice and exploration and needs to constantly explore new teaching mode to adapt to requirement of educational cultivation objective under new situation. Local college's development of pottery-art course should combine with its own regional features, school running level and professional direction, fully use existed art resource and adopt its good points and avoid its shortcomings to make pottery-art course teaching impressive.

\section{REFERENCES}

[1] Academy of Fine Arts of Tsinghua University Chinese Art Design Education Development Strategy Research Group. Chinese Art Education Development Strategy Research [Z] . Tsinghua University Press, 2010, 10

[2] Xiong Qingzhen. Attempt and Thought on Local Colleges Carrying Out Pottery-Art Practice Teaching [J] . Jiangsu Ceramic, 2009, 42 (5)

[3] Huang Zhenwei. Regional Cultural Features and Modern Pottery-Art Teaching $[\mathrm{J}]$. Art Panorama, 2009, 08 